\title{
走査型イオン伝導顕微鏡のバイオ応用
}

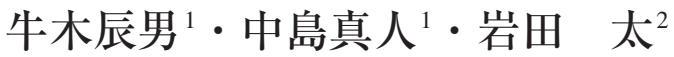 \\ 1新潟大学大学院医歯学総合研究科 顕微解剖学分野 正951-8510 新潟県新潟市中央区旭町通 1 番町 757-5 \\ 2静岡大学大学院工学研究科 機械工学専攻 機械工学科 — 432-8561 静岡県浜松市中区城北 3-5-1
}

（2013 年 5 月 29 日受付；2013 年 7 月 16 日掲載決定）

\section{Biological Application of Scanning Ion Conductance Microscopy}

\author{
Tatsuo UshiKI ${ }^{1}$, Masato NAKAJIMA ${ }^{1}$ and Futoshi IwAta $^{2}$ \\ ${ }^{1}$ Division of Microscopic Anatomy, Niigata University Graduate School of Medical and Dental Sciences, \\ 757-5 Asahimachi-dori-1, Chuo-ku, Niigata 951-8510 \\ ${ }^{2}$ Department of Mechanical Engineering, Graduate School of Engineering, Shizuoka University, \\ 3-5-1 Johoku, Naka-ku, Hamamatsu, Shizuoka 432-8561
}

(Received May 29, 2013 ; Accepted July 16, 2013)

\begin{abstract}
Scanning ion conductance microscopy (SICM), first introduced by Hansma et al. (1989), can obtain topographic images of the sample surface and has been expected to be useful for biological studies. In this paper, we explained the principle of the SICM and showed some results of the application of SICM to biology. We showed SICM images of collagen fibrils, chromosomes and cultivated cells in liquid. We then applied SICM for imaging the surface of tissue blocks (e.g., trachea, etc.). Sequential time-lapsed SICM images of live cells were also shown for revealing the movement of cellular processes on the time scale of minutes. The advantages of SICM imaging in biology were discussed by comparison with atomic force microscopy (AFM) and/or scanning electron microscopy (SEM) images.
\end{abstract}

KEYWORDS : scanning ion conductance microscopy, collagen fibrils, chromosomes, cultivated cells

\section{1.は じめに}

走査型イオン伝導顕微鏡 (scanning ion conductance microscope, SICM) は, 走查型プローブ顕微鏡（scanning probe microscope, SPM）の仲間として, 1989 年に P.K. Hansma らによって提案された ${ }^{1)}$ 。SPM と呼ばれる 一群の顕微鏡は, 探針（プローブ）を試料表面に走査す るタイプの顕微鏡の総称で, 探針を試料表面に近接させ た際に生じる探針・試料間の物理化学的情報を信号とし て，探針を制御しながら，何らかの画像を得ることがで きる。このうち, 生物学分野でもっと広く利用されてい る SPM は，探針・試料間の相互間力を制御する原子間 力顕微鏡 (atomic force microscope, AFM) であるが2,3), ここで紹介する SICM では, 探針にマイクロガラス電極 を用い, 液中に留置した対照電極との間に生じるイオン

E-mail : t-ushiki@med.niigata-u.ac.jp
電流を測定・制御しながら，画像を形成する。

SICM はAFM と同様におもに試料の表面立体形状を 画像化する顕微鏡であるが，液中での観察に特化してい る点や, 試料に接触することなく観察ができる可能性を 秘めている点で, とくに最近ではそのバイオへの応用が 注目され始めている ${ }^{4 \sim 7)}$ 。

ここでは, SICM の基本原理を紹介するとともに，そ の生物応用の実際を筆者らのデー夕を中心に紹介し, こ の顕微鏡の今後の可能性について考える。

\section{SICM の原理と装置構成}

\section{1 基本原理}

上で簡単に述べたが，SICM は探針にマイクロガラス 電極を使用する（Fig. 1 a）。この電極は, 先端開口径が $100 \mathrm{~nm}$ 程度のガラスピペットからなり，その中には塩 化銀でコートした銀電極が扱入され，電解質が満たされ ている。一方, 対照電極として, 別の銀電極が試料を入 


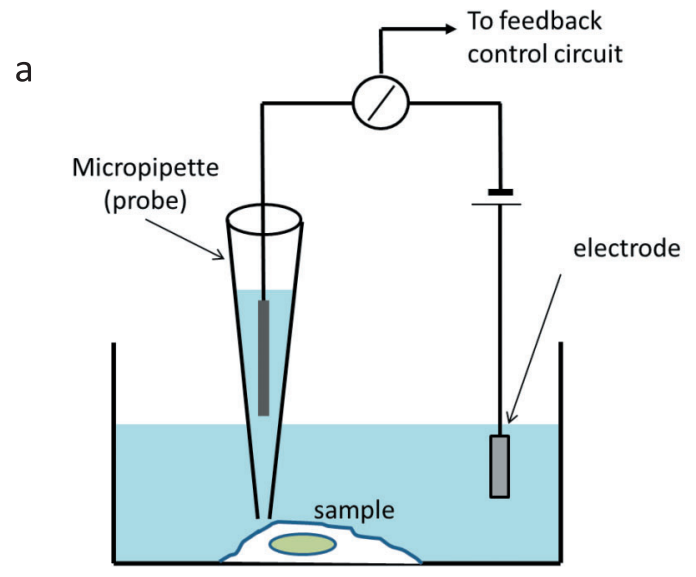

b

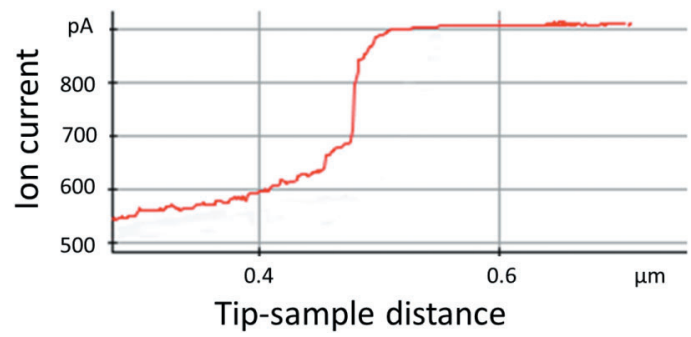

Fig. 1. (color online). The principle of SICM (a) and an approach curve showing the relationship between the ion current and tip-sample distance (b).

れた液中セルの中に留置されているので，電極間に電圧 をかけるとイオン電流が流れることになる。SICMで は, このイオン電流を探針 (ガラス電極) の制御信号と して利用している。すなわち，探針を試料表面に近づけ ていくと，ガラス電極の先端が少しずつ試料に遮蔽され るために，イオン電流が減少する（Fig. 1 b.)。この減衰 率をもとに探針の位置を $\mathrm{z}$ 方向に制御しながら $\mathrm{xy}$ 平面 に走査し, 試料の表面形状を画像化する。

このようにSICM では，探針と試料間の制御にイオン 電流を用いることから，制御の仕方によっては探針を試 料にじかに接することなく, 表面形状の画像化が可能と なる。この点で, これまでバイオに用いられてきた AFM とは大きく異なっている。

\section{2 測定モード}

SICM の主な測定モードには次のようなものがある (Fig. 2)。

1）直流モード (DC mode)：探針（ピペット）をイオ ン電流の変化が生じるまで試料に接近させた後に，この 状態を維持して試料表面を走查し，表面像を得る ${ }^{4}$ 。

2）交流モード（AC mode）：探針を小さく振動させた 際に生じるイオン電流の振幅を, ロックインアンプを用 いて検出する。この場合, 試料に探針が接近すると, イ
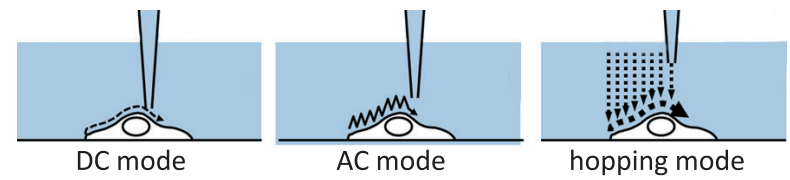

Fig. 2. (color online). Operation modes of SICM.

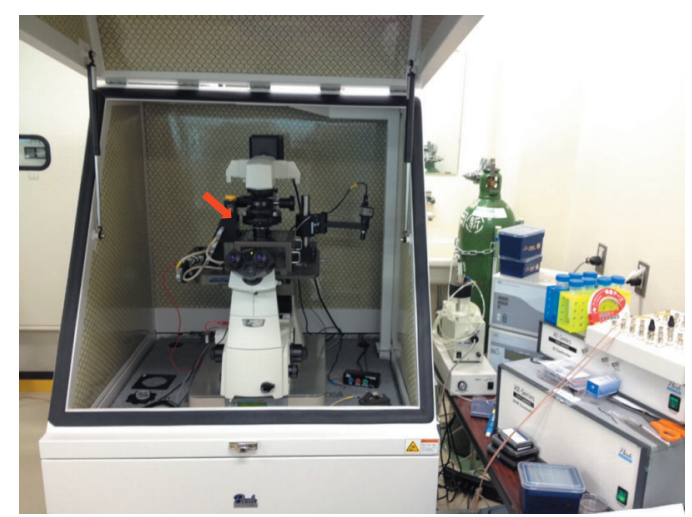

Fig. 3. (color online). View of an SICM (XE-Bio system).

オン電流の減少に伴いこの振幅が増加するため, これを 指標に試料表面を走査し，画像を取得する。

3）ホッピングモード (hopping mode) : 最初に試料か ら遠ざかった位置に探針を引き上げ，その後にイオン電 流をモニターしながらピペットを試料へと接近させ る5)。この際，ピペットと試料が接近しすぎないよう に, イオン電流の減少量に間値を設定し, その間値まで イオン電流が減少したところでピペットを引き戻す。こ の動作を $\mathrm{xy}$ 平面の各走查点で行うことで, 表面形状を 画像化する。その動作から, バックステップモード (backstep mode) とか ARS モード (approach-retract scanning mode）と表現する場合もある。このモードはほか の二つのモードと異なり，探針を引き上げる距離を調節 することで，凹凸の激しい試料表面の観察ができるとい う利点があるが, 一方で測定に時間がかかる点と, 分解 能が若干劣る傾向があることは注意すべき点である。

\section{3 装置構成}

一般に SICM は倒立顕微鏡のステージの上に搭載して 使用されることが多い。私たちが主に使用している装置 (XE-Bio system, Park Systems Corp.) も，Fig.3のように 倒立顕微鏡の上に搭載されている。この装置では, $\mathrm{xy}$ 平面の走查を行う圧電素子（ $\mathrm{x}, \mathrm{y}$ スキャナ）がステー ジ上に配置され, 垂直方向の走查を制御する圧電素子 ( $\mathrm{z}$ スキャナ) は別に配置されている。探針（ピペット） は $\mathrm{z}$ スキャナに固定してあり, 試料を入れた液中セルの 
中には，対照電極が留置してある。一般に生物試料は凹 凸の激しいものが多いことから, 今回の生物試料の観察 にはホッピングモードを用いた。なお, ガラスピペット は通常のボロシリケイトのキャピラリー管（内径 0.6 $\mathrm{mm}$, 外径 $1 \mathrm{~mm}$ ) をサッター社のレーザー・プラーで 引いて, 先端内径が $100 \mathrm{~nm}$ 程度, 外径が $200 \mathrm{~nm}$ 程度 になっているものを用いた。また, 測定時の電圧は約 $100 \mathrm{mV}$, 電流の大きさは約 $1 \mathrm{nA}$ とし, 測定時のイオン 電流は $0.6 〜 2 \%$ 減衰を閾值とした。

\section{SICM による生物試料観察(}

\section{1 コラーゲン細線維網の観察}

コラーゲン細線維は, コラーゲン分子が会合してでき る太さ数十〜数百 $\mathrm{nm}$ の長い線維状の構造物である。こ こでは, このコラーゲン細線維を豊富に含むラット尾腱 の小片をガラス上に載せ, これを薄く引き延ばしながら コラーゲン細線維をほぐして, ガラス上に伸展した。こ れを一旦乾燥させた後に生理食塩水またはリン酸緩衝液 に浸し，ホッピングモード SICM で観察した。

この標本ではコラーゲン細線維が縦横に重なり合って いるため, 一部の細線維は宙吊りになっている。 SICM ではこのような複雑な細線維網についても, きわめて明 瞭な画像を得ることができる（Fig. 4.）。このことは, SICM の測定においては, AFM と異なり, 試料に力が 加わりにくいことを示すとともに，ホッピングモードが 高低差の大きい試料にきわめて有用であることを示して いる。また, 内径 $100 \mathrm{~nm}$ 程度の探針（ピペット）を用
いた場合でも, 太さ $50 \mathrm{~nm}$ ほどの細線維が観察できる ことから, SICM の分解能は探針の内径よりも小さいこ とが想像される所見である。

\section{2 染色体の観察}

染色体は真核細胞の細胞分裂期に出現する DNA と夕 ンパク質の複合体である。分裂中期の培養細胞を回収

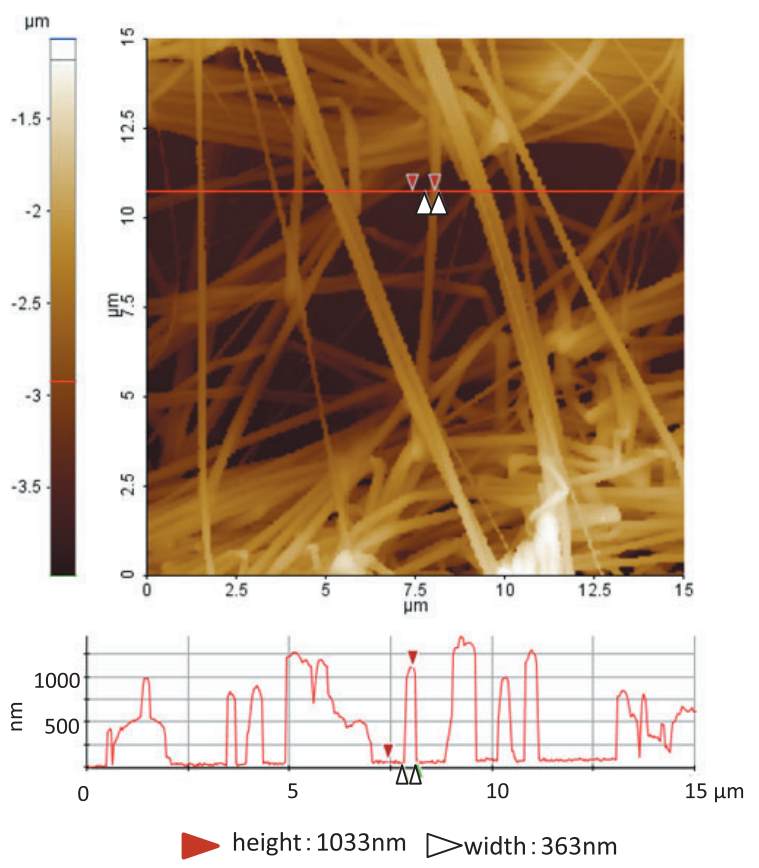

Fig. 4. (color online). Collagen fibril networks observed by hopping mode SICM.
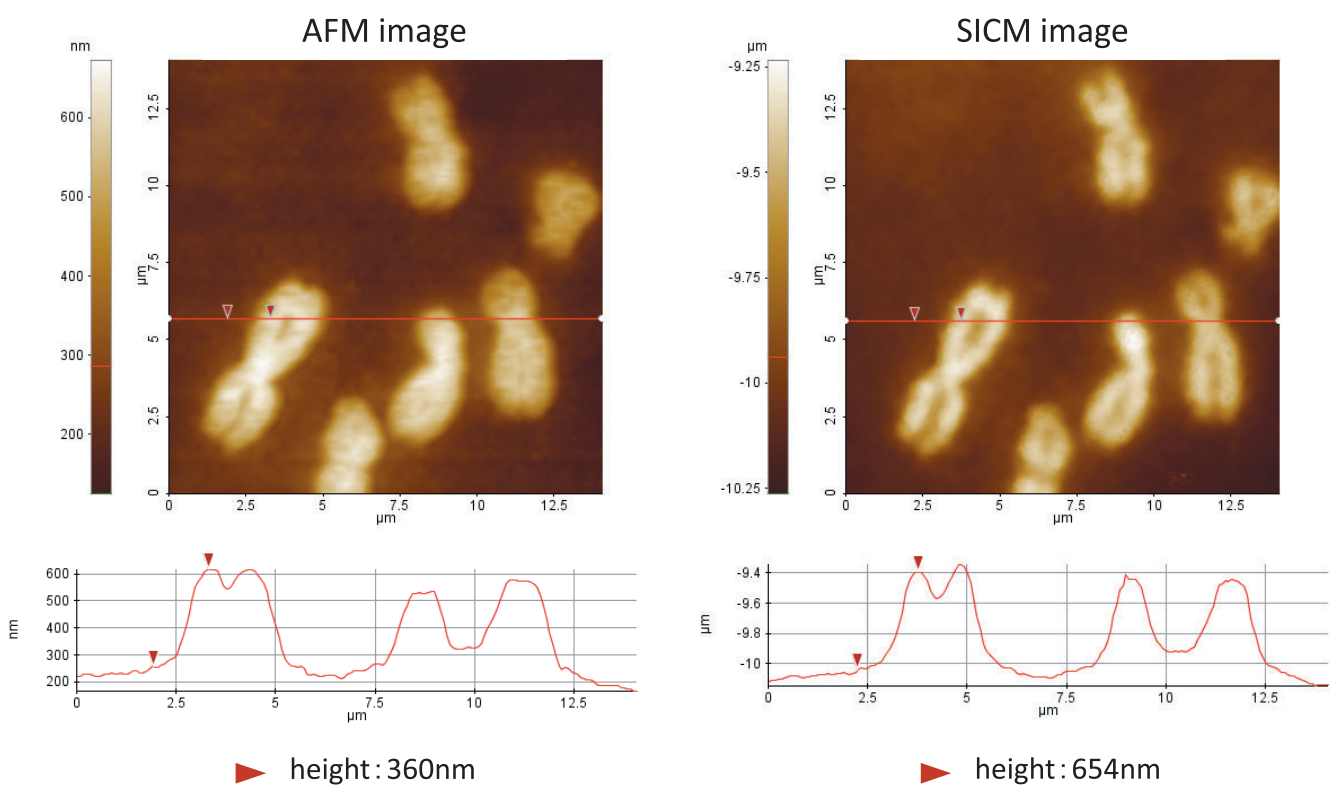

Fig. 5. (color online). Human chromosomes observed by AFM (left) and SICM (right). 


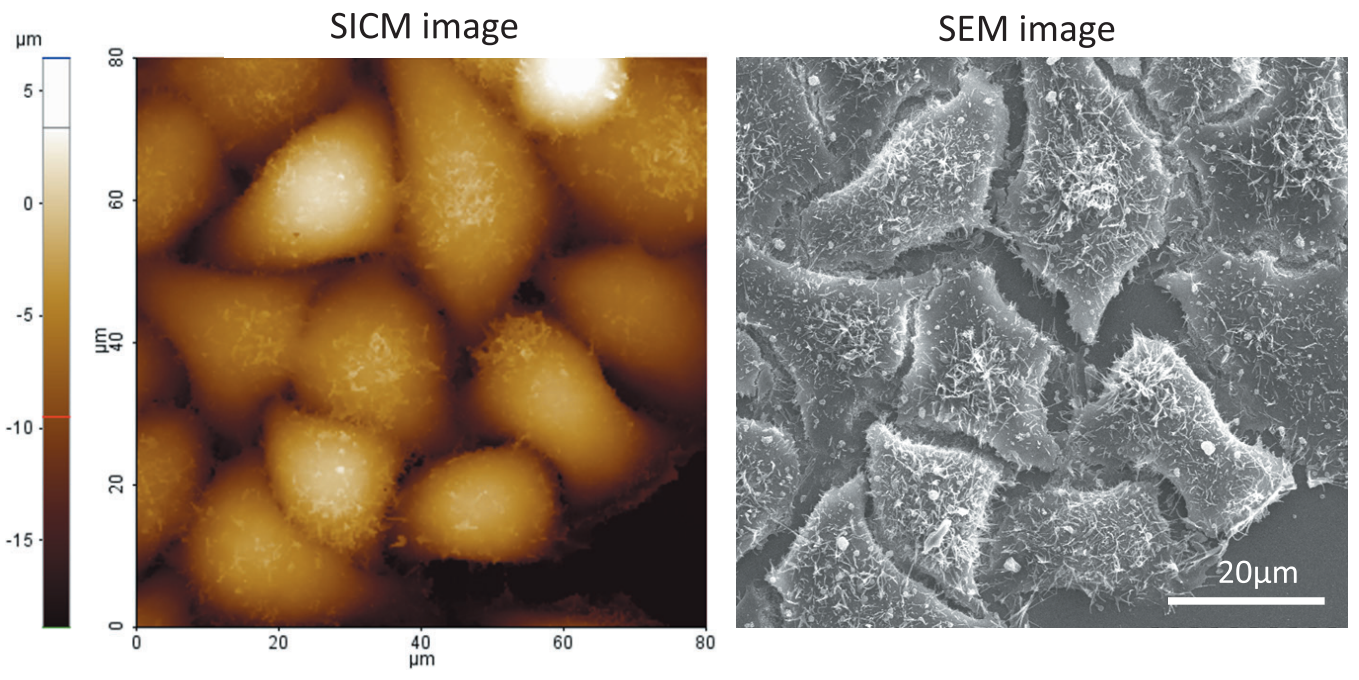

Fig. 6. (color online). SICM images of cultivated HeLa cells which was fixed with $2 \%$ glutaraldehyde.

し, 低張処理をしたのちに酢酸アルコール液（メタノー ル：酢酸=3:1）で固定したものを，ガラス上に滴下す ることで，ガラス表面に染色体を展開することができ る ${ }^{8)}$ 。この標本をリン酸緩衝液に SICM で観察すると, $\mathrm{AFM}$ と同様に染色体を液中で観察することができる ${ }^{6}$ 。

ちなみに同一の染色体を SICM と AFM で観察して比 較してみると, 得られる像はよく似ているが，染色体の 高さ (厚み) は, SICM で観察した染色体のほうが高く (厚く）見えることがわかる（Fig. 5)。これはSICM と AFM のどちらを先に観察しても変わらない。この結果 は, SICM では AFM より試料から離れた距離, すなわ ち試料に接触することなしに表面形状観察が可能である ことを示している。染色体は液中ではきわめて柔らかい 試料のため, AFM ではしばしば探針で押しつぶしてし まうことを思うと，SICM の有用性が期待される観察例 である。

一方で, SICM で染色体を観察する場合, バイアス電 圧の印加方向により画像の安定性が異なることがわかっ てきている。染色体そのものがマイナスに荷電している ことが原因と考えられるが，この点については現在，検 討中である。

\section{3 培養細胞の観察}

液中での培養細胞の表面立体形状観察は，これまで主

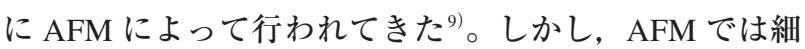
胞表面を引きずったり引っ掻いてしまうことも多く, 細 胞辺縁の基板に伸び出した突起の形状の観察はできて も, 細胞上部表面に伸び出した微細な細胞突起は，たと え細胞をグルタールアルデヒドで固定したとしても，探 針で押しつぶしてしまう傾向があった。
こうした細胞を SICM で観察してみると, 細胞辺縁の 突起に限らず, 細胞上部に伸び出した微細の突起につい ても明暸に観察できることがわかってきた ${ }^{4,6,10)}$ 。その 形状については，SICM で画像取得後に，同一標本を走 査電子顕微鏡で観察することでさらに詳しく検討するこ とができる（Fig. 6）。こうして SICM と走査電子顕微鏡 の像を比較してみると, SICM では乾燥による収縮の影 響を受けずに，ふっくらとした細胞像を取得することが できることがわかる。またグルタールアルデヒド等で固 定した細胞であれば，柔らかく微細な細胞突起について も，SICMにより液中で忠実に画像化できることがわか った。もっとも, HeLa 細胞のように細く長い細胞突起 が密集している場合は, 突起が液中で摇らいでしまうせ いか，SICM では観察できないこともある点は注意する 必要がある。

また，ホッピングモード SICM では， z スキャナの可 動範囲で凹凸の激しい試料も測定が可能である。実際 に，細胞の核のあるもっとも高い部分が $10 \mu \mathrm{m}$ もる ような背の高い細胞でも，探針を引きずることなく観察 を行うことができる点がホッピングモード SICM の魅力 である。

\section{4 組織試料の観察}

ホッピングモード SICM が凹凸の激しい試料の観察に 適していることを利用して, 走查電子顕微鏡のように組 織片の観察が可能かを，ラットの気管を例にして検討し てみた ${ }^{6)}$ 。

グルタールアルデヒドで灌流固定をしたラットの気管 を小片として切り出し，気管内腔面が上向きになるよう にガラスに瞬間接着剤（アロンアルファ）で固定したの 


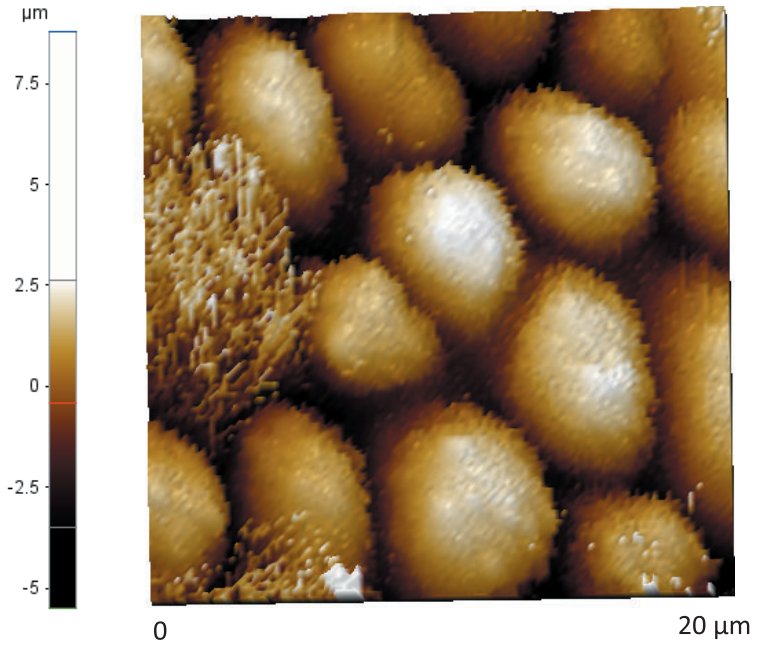

Fig. 7. (color online). SICM image of the luminal surface of tracheal epithelium.

ちに, SICM でその表面観察を行ったところ, 線毛細胞 の線毛や分泌細胞頂上部の微細突起などを明瞭に観察す ることができた（Fig. 7)。このことは， z スキャナの可 動範囲による制約はあるものの, 凹凸の激しい多様な組 織にSICM が利用できる可能性を示している。走查電子 顕微鏡とは異なり，標本を乾燥させることなく, 液中で の組織の表面形状を直接観察できる点で, 今後の展開が 大いに期待できるアプローチということができそうであ る。

\section{5 生きた細胞のイメージング}

これまで紹介してきた観察例は，コラーゲン細線維を 除き，いずれも細胞や構造物をグルタールアルデヒド等 で固定したものである。一方で，バイオの液中観察が可 能となった場合に，やはりもっとも期待されるのは，生 きた（すなわち未固定の）細胞の観察だろうか。その点 で, SICMによる生きた細胞の観察の可能性を考えるこ とはきわめて重要である。

生きた細胞を観察するには， $\mathrm{CO}_{2}$ インキュベータと同 様な環境を観察セル内に作るとともに，ドリフトを防ぐ ために温度の正確なコントロールが必要である。こうし た環境を作るための専用の液中セルを用意して, 生きた 培養細胞をそのまま SICM で観察を行うと, 液中での培 養細胞の観察が可能となる (Fig. 8)。これにより，いわ ゆるコマ撮り撮影を行うと, 細胞の輪郭の変化を観察す る程度のことは可能である。その際，1個の細胞を観察 する場合は, 表面の凹凸の激しいものが多いことから， ホッピングモード SICM が効果的である。

ただし，ホッピングモードSICM を用いる場合，どう しても 1 枚の画像の取得に時間がかかり, 現状ではせい

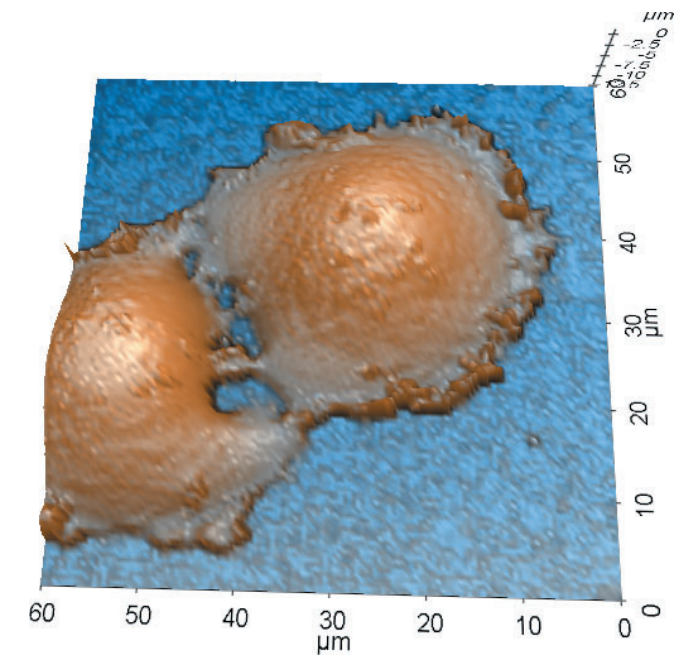

Fig. 8. (color online). SICM image of live culture cells.

ぜい $128 \times 128$ ピクセルの画像で 1 枚あたり 6 分程度が 限界である。その点で, 動きの速い細胞の観察には不適 であることから，この制限を克服する試みが今後さらに 期待されるところでもある。

\section{4. ま め}

本稿では, SICM の原理と基本的な装置構成を解説 し，バイオ応用のいくつかの例を紹介した。

SICM は, AFM と異なり, 制御信号にイオン電流を 利用することから，探針で試料表面に力を加えることな く試料の表面形状観察ができるという大きな利点を持っ ている。その点で, バイオの試料のようなきわめて柔ら かい素材の観察に適しており, AFM では難しかった培 養細胞の表面観察などに今後大いに期待が持てそうであ る。とくにホッピングモード SICM の出現で, 凹凸の激 しい構造でも観察が可能となってきており, 生きた細胞 の動的観察への期待も大きくなってきている。

一方で，SICM におけるバイオ応用は，イギリスのY. Korchev のグループによりほぼ独走態勢で進められてき たことから，他のグループによる報告が少なく，まだそ の応用例は限られており，その理論的な検討もそれほど 多くないのが現状である。その点で, 探針のピペット径 と分解能の関係や，試料のチャージがもたらすイオン電 流の変化など, まだ多くの基碟的な研究が期待されると ころでもある。

また，SICM はマイクロガラス電極を用いる点や，イ オン電流を信号として用いる点で, 生理学分野で用いら れるパッチクランプとよく似た構成をとっている。この ことから, SICM とパッチクランプとの併用方法による 細胞の表面形状と細胞膜電流の測定の組み合わせなども 
紹介されている ${ }^{11)}$ 。同様にSICM と走查型電気化学顕微

鏡 (scanning electrochemical microscopy) との組み合わせ も可能である ${ }^{12)}$ 。その点で, マルチプローブ顕微鏡とし ての利用を含め, SICM の今後の多様な発展が期待でき そうである。

\section{謝辞}

本研究の一部はパークシステムズのご協力により, 一 部は科学研究費補助金 (no. 21390051) と新潟大学プロ ジェクト推進経費 (発芽研究)によるものである。

\section{文献}

1) P.K. Hansma, B. Drake, O. Marti, S.A. Gould and C.B. Prater : Science 243, 641 (1989).

2) G. Binnig, C.F. Quate and C. Gerber : Phys. Rev. Lett. 56, 930 (1986).

3) T. Ushiki and K. Kawabata: "Applied Scanning Probe Methods X. Biomimetics and Industrial Applications”, ed. by B. Bhushan, H. Fuchs and M. Tomitori (Springer, Heidelberg, 2008) p. 285.

4) Y.E. Korchev, C.L. Bashford, M. Milovanovic, I.
Vodyanoy and M.J. Lab : Biophys. J. 73, 653 (1997).

5) P. Novak, C. Li, A.I. Shevchuk, R. Stepanyan, M. Caldwell, S. Hughes, T.G. Smart, J. Gorelik, V.P. Ostanin, M.J. Lab, G.W. Moss, G.I. Frolenkov, D. Klenerman and Y.E. Korchev : Nat. Methods 6, 279 (2009).

6) T. Ushiki, M. Nakajima, M. Choi, S.J. Cho and F. Iwata : Micron 43,1390 (2012).

7) P. Happel, D. Thatenhorst and I. Dietzel : Sensors 12, 14983 (2012).

8) O. Hoshi, R. Owen, M. Miles and T. Ushiki : Cytogenet. Genome Res. 107, 28 (2004).

9) T. Ushiki, S. Yamamoto, J. Hitomi, S. Ogura, T. Umemoto and T. Shigeno: Jpn. J. Appl. Phys. 39, 3761 (2000).

10) J. Rheinlaender, N.A. Geisse, R. Proksch and T.E. Schaffer : Langmuir 27, 697 (2011).

11) Y. Gu, J. Gorelik, H.A. Spohr, A. Shevchuk, M.J. Lab, S.E. Harding, I. Vodyanoy, D. Klenerman and Y.E. Korchev : FASEB J. 16, 748 (2002).

12) Y. Takahashi, A.I. Shevchuk, P. Novak, Y. Murakami, H. Shiku, Y.E. Korchev and T. Matsue : J. Am. Chem. Soc. 132, 10118 (2010). 